Valóságos könyvtár - könyvtári valóság. Könyvtár- és információtudományi tanulmányok 2016. Szerk. Kiszl Péter, Boda Gáborné Köntös Nelli.

Budapest, ELTE BTK Könyvtár- és Információtudományi Intézet. 2017. 21-28.

\title{
MENTEM-É A KÖNYVTÁRAK ÁLTAL ELÉBB?
}

\section{DÉRI BALÁZS}

ELTE BTK Ókortudományi Intézet Latin Tanszék, tanszékvezető egyetemi tanár

\begin{abstract}
ABSZTRAKT
Igen, biztosan, és nem is tudom eldönteni, melyik volt a legfontosabb. Gyermekkorom falusi művelődési házának könyvtára, amelyet lényegében végigolvastam? (Nem volt nehéz.) Egyetemista éveimben a Széchényi Könyvtár a Nemzeti Múzeum épületében, az Egyetemi, meg a kari magyar nyelvészeti könyvtár, Gabikával, és mindenekelőtt az Akadémia Keleti Könyvtára? (Írnám én a latin tanszéki könyvtárat is, de olyan nem volt, pontosabban a tanárok szobájában meg a szemináriumban leledztek a hozzáférhetetlen könyvek.) Fiatal kutatóként a barcelonai Katalán Nemzeti Könyvtár, annak is a szabadpolcos folyóiratolvasója? (Ott lettem medievista.) Az oxfordi Bodleian, az utóbbi 15 évben évenkénti zarándoklattal? (Végre, egy igazi-igazi könyvtár.) Igen, de mindnél inkább klasszika-filológiai tanszéki könyvtárunk, amelynek könyvei a Pesti Barnabás utcából a Kecskemétibe költözve összeköltöztek, míg 10 éve a Trefort-kerti F épület rossz hírű Erdős Caféja helyén egy félszuterénben találtak helyet. Olyan, amilyen, dohos is, foghíjas is, de a legjobb görög-latin könyvtár, és a miénk. A belső udvarra néző középkoros-patrisztikus kabinet a dolgozószobám. Saját sokszáz, örökre átadott könyvem is itt van körülöttem. Máshova csak nagyon határozott céllal megyek. Két vágyam van: nyugdíjas koromban ingyenes segédkönyvtárosként itt maradhassak, és megérjem, hogy a világ összes könyvtárának minden kézirata, és minden könyv digitálisan hozzáférhető legyen. Bis hundertzwanzig. Miért is lenne lehetetlen gondolat, itt, a könyvtárban?
\end{abstract}

Igen, biztosan, még ha a középfokú nyelvtani alakban rejlő összehasonlítás elméletileg nem is problémamentes. Hiszen kihez-mihez képest? Lehet-e összehasonlítani azt a valóságosan létező Déri Balázst, aki fél életét könyvtárakban töltötte, azzal, aki könyvek és könyvtárak nélkül élt... volna, születési nevén Déri Tiborként?

Bár a cím, Vörösmarty-vers parafrázisa, heroikus-pesszimista tónust sejtet, optimista leszek. Kezdjük a legvégéről: könyvtár - mégpedig a Latin Tanszék könyvtára - a dolgozószobám. Verseimben egyik alteregóm, vagyis a modern osztott-hasadt személyiség egyik rész-személyisége Epignómidés, az alexandriai Könyvtár soha-nem-volt könyvtárosa. Nem is olyan régen, alig két évtizede, ami csak egy fiatal ember életében idő, nagy könyvtárat kellett volna feltúrni ahhoz, hogy kiderüljön: soha nem volt ilyen könyvtáros a Könyvtárban. Ma pár perc kattintgatással igen megnyugtatóan valószínűsíteni lehet a turpisságot. Ezzel is a könyvtárról beszélek, másféléről, más szerepűről, részben virtuálisról, de könyvtárról. Válaszolhattam-e hát nemmel Kiszl Péter kolléga megtisztelő fölkérésére másképpen, mint azonnal igennel. Különösen mert nem tudományos érvelésre, nézetek ütköztetésére kért föl, még csak nem is arra, hogy a szakmám szerint 


\section{DÉRI BALÁZS}

elvárható módon az alexandriai vagy különösen a római könyvtárak manapság igen erőteljes kutatását mutassam be, hanem történetmesélésre vett rá. Remélem, valamivel több lesz belőle, mint egyszerű „sztorizás”.

Hogy elébb mentem-é, azt, ha elméletileg lehetséges volna, akkor sem lenne dolgom eldönteni. De hogy más lettem, az bizonyos. Gyermekkoromat egy, a fővárostól 40 kilométerre fekvő kisközségben, Tápiósülyben töltöttem. Születésem után pár hónappal Orgovány legszélsőbb tanyájáról, a bugaci puszta mellől, e kis falu külterületére, egy tanyabokorba költöztünk, de az iskolát 1960-ban már a faluban lakva kezdtem. Nagyparaszti, hajdan kispolgári magasságba ácsingózó, aztán háborús és kuláküldözős időkön keresztül munkáslétbe lecsúszott családunkban édesanyám nevelésének legfőbb célja az ő megvalósulatlan, s persze csak homályos célokra irányuló műveltségi aspirációinak beteljesítése lett. A háztartásbeli, majd kórházi, s még később vasúti éjszakai takarítónő, legvégül pénztáros egyetlen pihenése, gyönyörűsége pedig az olvasás volt. Nem csak hitbuzgalmi irodalmat és Bibliát olvasott, amint egy derék puritán vallási közösségben illett, hanem regényeket, életrajzokat is, hogy legalább fantáziavilágában elemelkedhessék a földhözragadt mindennapoktól. De anyai nagyanyám is, aki egyetlen osztályt sem járt, csak édesanyjától tanulta meg a betûvetést és a számolást, igen sokat olvasott. Leginkább az útleírásokat szerette, meg a történelmet. Sajátos rendben értette meg őket, vagyis összevissza, de ettől is boldog volt. Anyám, hogy többet tudjon s a fiának ne kelljen szégyellnie a tanulatlanságát, a hatodik elemiben abbamaradt tanulmányait a nyolcadikig befejezte. (Első, tanyasi iskolája az utolsó lett, ahol osztatlan formában oktatás folyt, egészen a rendszerváltozásig. Még meg lehetne menteni a tanyasi Klebelsberg-iskolát... Múzeumnak). Tehát előttem két évvel haladva elvégezte a dolgozók általános iskoláját. Mindig büszke volt arra, hogy jobban ismerte az irodalmat, mint maguk a bizonyosan elég gyönge általános iskolai tanítók.

Szegények voltunk, még a nagyon szegény falu átlagánál is szegényebbek. A gazdagabb múltból csak pár tucatnyi könyv maradt meg, de nagy becsben tartva. Vásárlásra lényegében nem jutott: karácsonyra, húsvétra, születésnapra kaptunk egy-egy könyvet, azokhoz jöttek az iskolai ajándékok. Az első saját könyvek. Hatéves koromban karácsonyra megkaptam akkori vallási közösségünk új énekeskönyvét. Fél év után már jól tudtam olvasni, hiszen nem a funkcionális analfabétizmusra előkészítő ostoba olvasás-,tanítási” módszerekkel tanultunk. Kottát pedig már a betûk előtt is olvastam, mert egy amatőr zenei alaptanfolyamon lábatlankodva megtanultam; ahogy lényegében magam tanultam meg a hangszerjáték alaplépéseit is. Az énekeskönyvben leginkább az indexeket, a himnológiai jegyzeteket szerettem, hamar betéve tudtam őket. És íme, zenetudós lettem, a huszonkét éve általam alapított Magyar Egyházzene című szakmai folyóirat felelős szerkesztője vagyok.

Anyukám magának, de nekem s később öcsémnek is a falusi művelődési ház könyvtárából kölcsönzött könyveket; éjszakai műszakból hazafelé bukdácsolva hetentekéthetente tért be az állomásról hazafelé útba eső könyvtárba. Már 9-10 évesen én is odaszoktam. A könyvtárba, meg a szakkörökbe. Ó, falusi múvelődési házak, apró, szét- 
olvasott könyvtárak, lelkes-botcsinálta népmúvelők, mentem, mentünk volna nélkületek elébb? Faltam a könyveket, előbb meséket, aztán 9-10 évesen, nagyanyámmal együtt, az útleírásokat. Még megvannak azok a kisalakú jegyzetfüzeteim, amelyekbe az ismeretlen szavakat gyűjtöttem ki szép akkurátusan. Az Ibn Battúta útjairól szóló könyvből oldalakon sorjáznak az arab, perzsa, török szavak, kifejezések. Nos, az egyetemen iranisztikát végeztem, és Indiában, Egyiptomban, Törökországban, s legutoljára, a legutolsók között, Szíriában gyűjtöttem zenét. Közel negyven év múlva teljesült a vágyam, hogy Aleppóba menjek. Ugye, sejtik, hogy mit gondolok? Mi is dőlt el kilencévesen?

Ahogy más is. A falusi szatócsbolt üres, poros kirakatában, ahová gyakran küldtek vásárolni, egyszer megjelent egy könyvecske. Még ma is előttem van, ahogy megláttam az Olcsó Könyvtár sorozat négyforintos könyvét. Az Ilias első tizenkét énekét. Fogalmam sem volt, hogy hogy nevezik vagy egyáltalán nevezni kell-e valahogy, de rájöttem a hexameter kényszeres lüktetésére. Nem is hiányzott nekem a folytatás. Az egyetemen a görög szakon aztán elolvastam, végig, a második tizenkét éneket is. És, ime, az utóbbi években itt a Karon a kreatív írás minor keretében metrikát, legelőször mindig hexametert tanítok. Ekkorról is megvannak a jegyzetfüzeteim: szétolvastam az ókori mitológiát. Ma is megvan Boronkay Iván Római regék és mondák című kötete, szüleim húsvéti ajándéka 1966-ból. És íme, Boronkay Iván 18 évig volt főnököm a Magyarországi Középkori Latinság Szótárának szerkesztőségében. Ami ma vagyok, az voltam már 1966-ban, 12 éves koromban is. Nem véletlen, hogy hagyományos kultúrákban ez a nagykorúság határvonala. Ezen az sem módosít, (csak mélyrétegekbe bukott le a korai élmény, hogy 18 éves koromban újra felbukkanjon), tehát nem módosít ezen, hogy kamaszkorom sokkal inkább telt a természettudományos könyvek olvasásával. Akkoriban falun nem volt felvilágosítás, az iskolában sem. Innen-onnan hallottunk, általában nagyobb testvérektől, ezt-azt. Azt sem tudtam, hogy hol keresgéljek a könyvtárban, (azt azért éreztem, hogy ott megtalálom a válaszokat, mert a könyvtár mindenre választ ad), mígnem megtaláltam az „orvosi” könyveket, s bennük azokat a bizonyos információkat... Jóleső volt az ismeretek biztonsága. Természettudományos érdeklődésem is a tápiósülyi, majd a jóval nagyobb gyömrői községi könyvtárban bontakozott ki. Az otthoni viszonyok elől is menekülve délutánjaim vagy növénygyújtéssel a határban, vagy a hajdani katolikus közösségi házból lett múvelődési ház könyvtárában teltek, amikor épp nem a szomszédban voltam, a templomban, orgonán gyakorolni, vagy a káplántól, az egyetlentől, akitől lehetett a faluban, latint tanulni. Az alvóvárosi közönség olvasását Kassai néni, egy nyolc osztályt meg valami tanfolyamot végzett könyvtáros irányította. Mindenkinek tudott ajánlani könyvet, mert „,mindent” elolvasott, s még tisztes vásárlási kerete is volt: a külön kívánságokat is teljesítette.

Az egyetem. Nem is tudom eldönteni, melyik volt a legfontosabb könyvtár egyetemi éveim alatt. Hol ez, hol az, amint érdeklődésem módosult. A Latin Tanszéken meg a Görögön a szemináriumi könyvtárban órák voltak, ritka nap, ha az ember jóban volt Rimóczi Mártával, és kisebb szolgálatokat tett neki, akkor hozzájutott egy-egy könyvhöz. De a legfontosabb könyvek meg a folyóiratok a tanári szobákban voltak. Olvasóterem 


\section{DÉRI BALÁZS}

nem létezett. Hallottam például, hogy van egy nagyon nagy szótár, a Thesaurus. Úgy ejtették ki a tanárok a nevet, mint valami nagy misztériumot. A Thesaurus a professzori íróasztal mögött volt, üvegszekrényben. Olyan heves vágy gyötört érte még később is, hogy amikor egy egyetemi könyvtári kolléga autót akarván vásárolni, eladta a sorozatát, haladéktalan megvettem. Olvasni, akár két óra közt tanulni hát a magyar nyelvészeti könyvtárba jártunk, a felejthetetlen Kiss Gabikához. Esténként a Széchényi Könyvtárba, a Nemzeti Múzeum épületébe vagy kölcsönözni a Szabó Ervin Könyvtárba. „Ah kínos élet, reggel estve öltözni-vetkezni kell”, olvastuk a Hídavatás adekvát sorait a ruhatárban.

Később az iranisztika, leginkább Telegdi Zsigmond ajánlásai határozták meg könyvtárválasztásomat. Az általa irányított vallástudományi tanulmányaimhoz az Egyetemi Könyvtár volt a bázis, sokszor kölcsönöztem ki neki is könyveket; de figyelmeztetett, másnak csak annak az olvasójegyével szabad kölcsönözni, s ezt ő is megtartotta. Illetve, hogy szabad, sőt hasznos is bejegyzéseket írni, de csak a legfinomabb ceruzával, és csak a lapszélre. Nyelvészeti, klasszika-filológiai, vallástörténeti könyvek százai őrizhetik szépségesen hurkolt betűit. Elég elolvasni, amit ő kiemelt, hihetetlen nyelvtudása pedig a világnyelvek és számos keleti nyelv szövegeinek javítására is feljogosította. A tanulmányok vége felé az Akadémiai Könyvtár Keleti Gyüjteményébe szoktam át. Vezetője tartotta nekünk a perzsa nyelvgyakorlatot, és orientalista diákok, fiatal kutatók, ott találkoztunk rendszeresen. Nagy tanáraink velünk szemben vagy mellettünk. És akárhányszor magán-kiselőadásokat is tartottak, vagy segítettek tudományos kérdésekben. A folyosó másik végében, a nagyolvasóban, ahol sokkal tovább maradhattam, hogy az Akadémia utcai hitvány albérletbe minél később kelljen hazamennem, a második egyetem múködött. Patrisztikus és vallástudományi érdeklődésem miatt elsősorban Vidrányi Katalin mellé csapódtam, de Kiss János, Bencze György és sokan mások, meg azok a morzsák, amik asztalukról lehullottak, talán fontosabbak voltak, mint az olvasás.

Az említett szótárszerkesztőség, első munkahelyem akkoriban az Eötvös Kollégium egy szobájában, az irodalomtudományi intézeti szárnyon múködött. Két turnusban dolgoztunk hatan-heten, így engem évekre a kollégiumi könyvtár raktárának egy hátsó szögletébe telepített főnököm. Az az igazság, hogy elég konfliktusos volt a viszonyunk, de kivel nem vagyok konfliktusban... Legelőször az ókortudomány bibliográfiájának készítésével foglalkoztam egy teljes éven át. Feladatom az ókori Kelet és a vallástudomány részmunkája volt, de lényegében a könyvtár teljes ókori és keleti anyaga átment a kezem között. Kevés hasznosabb dolgom volt az életemben. S hogy mit jelent a közvetlen hozzáférés, nem pedig kérőcédulák után a könyvre várni, mit jelent célzott keresés helyett csak úgy, megérzés alapján, csak úgy, ezt-azt a polcról leemelve vagy polcokat végiglapozva olvasni, azt ezekben az években tapasztaltam meg. Hogy aztán egy sokkal nagyobb kincstárba jussak.

28 éves koromban jártam először ösztöndíjjal Barcelonában, s napjaim az első egy hónap alatt nagyrészt a Nemzeti Könyvtárban teltek. Az óváros eme középkori, gótikus épülete, hajdan leprakórház, hatalmas termeiben szabadpolcon találtam az engem érdeklő (minden érdekelt!) ókortudományi, középkortudományi folyóiratok százait, és mivel ínhüvelygyulladás miatt nem tudtam jegyzetelni, volt, hogy a kérőlapot sem tudtam ki- 
tölteni, csak lapozni, hát, azzal töltöttem az időt, hogy a középkoros katalanisztikai témámat alaposan kibővítve sokszor órákon keresztül ácsorogva a végeláthatatlan polcok előtt, hol ebbe, hol abba belekapva olvastam. Valójában ez és a következő talán tíz év rendszeresen ismétlődő alkalmai lettek az én általános medievisztikai képzésem.

De a könyvtár nemcsak könyv, folyóirat és kéziratok. Hanem könyvtárosok, előbb csak segítőkész emberek, aztán barátok. Egy alkalommal, már sokadjára, kérőcédula kitöltésére kértem egy rokonszenves könyvtárosnőt, aki végül rákérdezett, hogy miféle csodabogár vagyok. Máig tart vele és családjával a mély barátság. Talán felerészben nekik köszönhetem Katalónia módszeres kirándulásokon való megismerését, de hetekre kölcsönkaptam vidéki házukat is, minden hétvégén egész heti étellel fölszerelve, hogy fordításaimat készíthessem. Gazdagok, megtehették, de akkor is baráti gesztus volt: egy könyvtárban megalapozott barátságé. Csak természetes volt akkortájt az is, hogy szinte ingyen másolhattam képtelen mennyiségű anyagot, és amikor szükségem volt valamire, bármikor utánam küldték postán. Ettől kezdve évente egyszer-kétszer, volt, hogy többször is kijutottam, sôt a nyolcvanas években fél évig egyetemi órákra is jártam, s témám, Raimundus Lullus és más középkori szerzők szakirodalmán kívül kéziratokat is tanulmányoztam, a barcelonai teológia könyvtárától kezdve a mallorcai katolikus teológián, a katedrális könyvtárában, a városon kívüli Real monostorában vagy a mallorcai Lullus Intézet March-könyvtárában. Az a bizalom és az a készségesség, amivel néha abszurd kéréseimet is teljesítették, (hazaindulás előtt mindenki nekem másolt...), ahogy odafigyeltek rám (Llorenç, a March könyvtárosa egy alkalommal tudtomon kívül odaszólt a Randa-hegyi ferenceseknek, hogy ha egy nagyon fáradt fura figura érkezik a rekkenő hőségben, akkor lássák el) katalán útjaimnak egészen különös tónust adtak. Ami meglepő: ez a készségesség ma, a professzionális, mindennel ellátott könyvtárak korában is mindenütt megmaradt. Nemcsak a katalánul beszélő közép-európai csodabogárnak szól. Fiatal kollégámmal pár éve is megtapasztaltuk ezt a megindító készségességet, nagyvárosi könyvtárakban éppúgy, mint vidéken.

Felejthetetlen az a pár forró hét is, amelyet, Rákóczi Ferenc néhány latin művének kiadása miatt, a Bibliothèque Nationale-ban és a troyes-i városi könyvtárban töltöttem. A rue Chrétien de Troyes-i könyvtár parányi olvasójában egy afrikai, egy koreai és egy magyar tudóska izzadt reggeltől estig a kéziratok fölött, hogy aztán a középkori épületekben valószínűtlen gazdag városban sétáljon, a korai zárás után némiképp bosszúsan... (Hosszú ennek az előtörténete. Megbízóimtól követeltem, hogy láthassam a kéziratokat, mert az autopsziát soha semmi nem pótolja. Ma ezt nem tehetném meg. Gonosz könyvtárosok attól kezdve, hogy digitalizálnak valamit, senki emberfiának nem mutatják meg.)

A 90-es években valósultak meg hosszú keleti utazásaim, amelyekről kisgyermekként álmodoztam. Bangha Imre indológus révén nemcsak India különböző részeit jártam be a Himalájától Ceylonig, Méghálaja államtól Rádzsaszthánig, Keralától Dardzsilingig, hanem oxfordi tanárságot elnyervén évente meghívott látogatásra, s most családja is rendszeresen vendégül lát. Neki köszönhetem egy igazi könyvtár rendszeres használatát. Hogy mit jelent egy szakkönyvtár, azt az oxfordi Keleti Intézet könyvtára mutatta meg. 


\section{DÉRI BALÁZS}

És hogy mi egy igazi-igazi nagy könyvtár, azt a Bodleian. A „minden elérhető” élményét. Az utóbbi 15 év évenkénti zarándoklatai legalább pár hétre azt az illúziót adják meg, hogy elvégre tudós lennék. Kialakult a könyvtárazás szertartása: reggel a Cherwell partján 8-ra imára sietek a Magdalen College kápolnájába. (Néha csak kettesben zsoltározgatunk Michael atyával.) Aztán egy gyors reggeli, majd 9-kor első vagyok a ruhatárban. Este 6-kor egy evensongon veszek részt valamelyik híres kórus énekével valamelyik közeli college-ban, majd utána vissza még három órára este tízig. A személyességből azért elég sokat veszített a könyvtár, ma már szakozatlan könyvet nem hoznak ki az embernek, bárhogy kéri, legföljebb a kedvéért gyorsan megcsinálják; azt hiszem, az olvasó is kevesebb, de a könyvtár nekem mégis csak „a” Könyvtár a digitális technikákra való átállás után is. Mindig találok egy kedves megértő könyvtárost, aki nem néz oda, amikor egy nap már 10-edszer viszem a szkennerhez vagy a xeroxhoz (persze, igen gondosan vigyázva az előírásokra, nem hajtva ki, nem nyomorgatva) azt a könyvet, amelyből mindig csak 5\%-ot másolok ki... És csak ritkán kell bosszankodnom, hogy nem pontosan ugyanazon a helyen van pár hónap múlva egy téma könyvanyaga, merthogy akkora a szaporulat, hogy néha át kell rendezni az égig érő szabadpolcokat... És ma már legalább olyan fontos a korlátlan digitális hozzáférés biztosítása is. A normális kép ez a mai könyvtárban: ott van előtted a laptop, rajta a digitális folyóirat vagy akármi más, de körbebástyázod könyvekkel. Másra használod, elmélyült olvasásra, ide-oda lapozásra a könyvet, és a gyors keresésre, pl. szótárban is, hiszen annyival könnyebb, a netet.

Igen, a Bodleian, de mindnél fontosabb nekem a mi (csak kelet-középeurópai mércével valaminek számító) klasszika-filológiai tanszéki könyvtárunk, amelynek könyvei a Pesti Barnabás utcából a Kecskemétibe jövén a tanári szobákból összeköltöztek, (nem egy kollégában alig múló sebet okozva, hogy kedvenc kötetei nem a keze ügyében vannak), míg tíz éve a Trefort-kerti F épületben, a rossz hírű Erdős Café helyén egy félszuterénben találtak helyet. Ó, ha egyszer elkészülne az omladozó E épület, és ha oda költözhetnénk...! Olyan helyről, amelyet az első pillanatban alkalmatlannak nyilvánítottak a szakemberek a könyvtári funkcióra. Azóta túléltünk egy borzalmas csőtörést, amely pótolhatatlan károkat okozott, s bár olyan, amilyen, dohos is, foghíjas is, de a legjobb görög-latin könyvtár a mi szemhatárunkon, és a miénk. Görögös, latinos és ókori filozófiás kollégáim pályázataik jelentős részét, sok tízmillió forintot fordítják, fordítottuk könyvvásárlásra, illetve ma már digitális anyagok beszerzésére is, hogy az alapvető kézikönyvek és a szakirodalom nélkülözhetetlen része, valamint a legfontosabb oktatási könyvsegédletek rendelkezésre álljanak. A pályázás eredménye persze nem csak tőlünk függ, így elég hektikus a beszerzés. De úgy látszik, állapítjuk meg szomorúan, ha valami elérhető, már nem is olyan érdekes. Sok hallgatónknak, látom, csak díszlet a könyvtár. Vagy céltudatosan veszik le, ami nekik kell. A véletlen fölfedezés élménye nem érinti meg őket.

A félszuterén belső udvarra nézô középkoros-patrisztikus kabinetje a dolgozószobám. Az sem ritka, hogy 12 órát töltök benne. Saját sok száz, örökre az egyetemnek átadott könyvem is itt van körülöttem, meg a tanszék emeletén tavaly az első 600 kö- 
tettel alapított vallástudományi-liturgikai szakkönyvtár-kezdeményben. Hivatalos dolgozószobámban a tanszék 17-19. század eleji anyaga található. Az ápolatlan, gombás állomány kezelésére nincs pénz. Az utóbbi években nem hallunk pályázatokról, amelyek az igen értékes, de fertőző állományt használhatóvá tennék. Egy vezető egyetemi könyvtári kolléga a szobában egyetlen szippantástól allergiás rohamot kapott. Kivizsgáltattam magamat, állítólag nem okozott fertőzést a tüdőmben, de mindenesetre jobb a felvégről az alvilági dohba levonulni. Máshova, más könyvtárba ma már csak nagyon határozott céllal megyek. Két vágyam van: nyugdijas koromban ingyenes segédkönyvtárosként itt maradhassak a tanszéken, valamint hogy megérjem: a világ összes könyvtárának minden kézirata, és minden könyv digitálisan hozzáférhető legyen. Bis hundertzwanzig. Miért is lenne lehetetlen gondolat, hátha elébb megy a világ, legalább ebben?

Igen, már mondtam: a saját könyvtárhasználatom is átalakult a kezdődő digitális korban. Figyelmesen, nyugodtan, feldolgozó olvasással szinte csak nyomtatott anyagot lehet olvasni, gondolom ezzel más is így van, ma is. Csak kényszerből folyamodom a nálunk beszerezhetetlen vagy nagyon sürgős könyvek internetes olvasására; vagy (az esőerdőket kockáztatva), kinyomtatva olvasom, ami fontos. Más a szánkázás a világhálón. A gyors ellenőrzés. A jegyzetkészítés... Jellemző a megoszlás: mostanában a fiatal kollégám, Földváry Miklós István által magyarországinak azonosított Benedictionale Strigoniense intertextuális hátterének felderítésével foglalkozom. Jobbomon a Patrologia Latina teljes sorozata: a figyelmes olvasásra. A gépen, az egyik képernyőn ennek digitális változata, a villámgyors rákeresésre. A másik képernyőre meg írok.

És milyen szívesen támaszkodnám hasonlóan megbízható digitális anyagokra magyar vonatkozásban is. Ezt várnám, várnánk el; vagy ha legalábbis átfogó koncepciót látnánk, túkön ülve, de szívesen kivárnánk pl. egy hibátlan MEK-et... Mert azért most nem egészen erről van szó. Micsoda hiányok! És klasszikus irodalmi szövegeinkben hemzsegnek a hibák. Az a legkevesebb, hogy a helyesírási sztenderdtől eltérő írásmód „,kijavul”, sokszor olvashatatlanok az időmértékes versek. Ments Isten, hogy csak úgy, alapos átolvasás nélkül improvizáljunk: a múltkor egy irodalomtörténeti órára nem vittem föl a megbízható nyomtatott szöveget, bekapcsolom a wifit, múködik, Oidipus király: bejön, felolvasom a szöveget, Apollónról szól, és előjön ez a szó: ,„jóisten”. Nekem még a leírt szó szent. Hirtelen elbizonytalanodtam. Te Jóisten, ez lenne a szövegben? Hát persze, hogy nem: ,,jósisten” kellett volna. Jó lenne, ha ugyanazzal a felelősséggel készülnének a mai digitális anyagok, mint a könyvnyomtatás legszebb napjaiban.

Pedig ma már könyvtártól és könyvtárostól ezt is elvárnám. Szép-szép, hogy amerikai könyvtárak beszkennelik a magyar kiadványokat, ha éppen az kerül a kezükbe, de tán a mi dolgunk lenne ez. A kulturális emlékezet átadásának harmadik nagy paradigmaváltásakor óriási, látható, megismerhető, megvitatható projektekkel kellene digitalizálni egész, egész írott és képi kulturális örökségünket. Nekünk, magyaroknak elsősorban a magyart. Ha már szegények vagyunk. Talán itt kellene szorgalmazni a digitális átállást; NKA-pályázóként (mint egy szakmai folyóirat főszerkesztője) tapasztalom, mindenáron a netre akarnak kiszorítani. Csak a netre. 


\section{DÉRI BALÁZS}

És amikor meg digitalizálni akarunk? A nevezett fiatal kolléga a Bölcsészkar legnagyobb futó OTKA-pályázatával a középkori latin liturgia teljes forrásanyagának feldolgozását tűzte ki célul, az általa kinevelt fiatal, nagyrészt még hallgatói munkatársi csoporttal. Szinte teljes anyaguk van már az ősnyomtatványok korából, a latin liturgia eme nagy rögzítésének idejéből, Írországtól Erdélyig. Az európai könyvtárak egy része rendkívüli energiákkal látszik digitalizálni anyagát, s a hozzáférés, ha sokszor borsos áron is, megoldható. Ugyanók számos kisebb helyen, vidéki francia, spanyol stb. könyvtárakban megrendelik a digitalizálást, és így a következő pár évben bizonyosan lényegében teljes anyaguk alakul ki ebben a kutatási körben. A nyomtatványok és kódexek tételenkénti leírása rendkívüli energiákkal folyik, a máshol kezdett projektek tapasztalatai alapján fejlesztett keresőopcióik már ma is elképesztő mennyiségben ontják magukból a rendszerezett adatokat. Nos, időről időre tárhelyet kunyerálnak az egyetemi informatikai igazgatóságtól, de nem azok jóindulata hiányzik ahhoz, hogy pl. egy adott ünnep vagy egy liturgikus tétel európai forrásai egy mozdulattal megjelenjenek a digitalizált kódex vagy nyomtatvány lapján. A továbblépést az egyetem tárhelyeinek bővítése jelentené e projektben, és máshol is. Az egyetem, ismereteink szerint meg is teremtette a fejlesztés anyagi alapjait. Igen ám, de beruházási tilalom van. Igen, beszerzési tilalom van: nem luxusfüggönyökre, ergonomikus székekre, hanem szerverfejlesztésre.

Végül, nem csak valamiféle munkakönnyítő eljárásról van szó. Legalább e tekintetben a kiteljesedő demokráciáról: az emberi kultúrához való egyetemes hozzáférésről a Föld bármely pontján.

Apokaliptikus napjainkban különösen fölerősödik bennem az a gondolat, hogy a végtelen sebezhető emberi kultúra legalább virtuális megmentésére mindenütt, de nálunk aztán különösen óriási energiákat kellene fordítani. A maiaknál sokkal többet. Lehet, hogy még kevesebb, bár ki tudja?, lenne a valóságos látogató, de virtuális látogatóként sem kevésbé szeretnénk és becsülnénk meg könyvtárainkat, mint az alexandriait, a Bodleiant, meg a kis falusi könyvtárat. Elég cudar a világ. De nem a könyvön és a könyvtáron múlott, hogy nem ment sokkal elébb. Adjunk neki még egy esélyt!

Déri Balázs klasszika-filológus, muzikológus egyetemi tanár, az ELTE BTK Professzori Tanácsának elnöke, a Vallástudományi Központ vezetője, az Ókortudományi Intézet Latin Tanszékének tanszékvezetője. 